\title{
Potential of Mangrove Ecosystem as a Tourism Object Development in Kaledupa Island
}

\author{
Amiruddin Akbar Fisu ${ }^{\mathrm{a}, 1, *}$, Afandi Ahmad ${ }^{\mathrm{a}, 2}$, Adrianto Hidayat ${ }^{\mathrm{b}, 3}$, Liza Utami Marzaman ${ }^{\mathrm{b}, 4}$ \\ ${ }^{a}$ Universitas Andi Djemma, Palopo, Indonesia. ${ }^{b}$ RISE Program, Makassar, Indonesia \\ ${ }^{1}$ amiruddinakbarfisu07@gmail.com*; ${ }^{2}$ afandi.ahd@gmail.com; ${ }^{3}$ hidayat.adrean@gmail.com; ${ }^{4}$ icamarz@gmail.com \\ * corresponding author
}

ARTICLE INFO (8 pt)

Article history:

Submitted: May 16, 2020

Reviewed: June 2, 2020

Accepted: June 15, 2020

Published: June 30, 2020

Keywords: Mangrove Ecosystem, Kaledupa Island, Ecotourism

\section{ABSTRACT (10PT)}

Mangrove forests that live in coastal areas, besides being beneficial for human needs, also often clash with development interests such as ports, fish ponds, and tourist areas that threaten their sustainability. Wakatobi Regency has the potential of living natural resources in the form of coastal and marine resources which are quite large, including mangrove ecosystems, seagrass ecosystems and coral reef ecosystems. The purpose of this study is to analyze the potential of mangrove ecosystems and to design the development of mangrove forests as an ecotourism potential. This research is a descriptiveevaluative research, with a qualitative approach. This research is important as a consideration in the development of attractions, which are the main sector in Wakatobi Regency. Mangrove species that dominate throughout the Wakatobi region are Rhizophora spp, Avicennia spp. and Sonneratia spp. Based on the potential of each island in Wakatobi Regency, Kaledupa Island is a priority area to be developed into ecotourism. This study recommends the construction of several supporting facilities for ecotourism on Kaledupa Island. Suggestions and infrastructure include service facilities, trade facilities and accommodation facilities.

Copyright () 2019 Politeknik Negeri Samarinda. All rights reserved.

\section{Introduction}

Mangrove forests whose position is on the coast often clash with development interests such as ports, settlements, tourist areas, and human use, among others as fishponds, charcoal producers and other needs, causing intervention and over-exploitation of mangroves and their ecosystems. This can be seen from the existence of land conversion (mangrove) into ponds, settlements, industries, etc. as well as logging by the community for various purposes. The high activity and accessibility to forest areas influences forest encroachment by the community (Ahmad, Wirakartakusumah, \& Rusolono, 2016). Efforts to use sustainable principles really need to be implemented in forest management where one form of management is the use of environmental services in the form of ecotourism (Nugraha, Banuwa, \& Widagdo, 2015).

Mangrove forests have a lot of potential to be developed as a tourist area (Idajati, Pamungkas, \& Vely Kukinul, 2016). Mangrove ecotourism is the sustainable use of mangrove forest ecosystems through environmentally responsible tourism activities (Nugraha et al., 2015). Mangroves can be used as nature-based tourist destinations and these activities contribute greatly to mangrove conservation (Hakim, Siswanto, \& Makagoshi, 2017). In addition, mangrove ecotourism can also provide socioeconomic benefits to local communities through the indirect value of natural resources 
(Basyuni et al., 2018), and can also support the activities of the fishing industry (Fisu, Didiharyono, \& Bakhtiar, 2020).

Utilization of mangrove forests is a form of sustainable management of natural resources but still requires consideration from various perspectives to produce appropriate policies (Hugé et al., 2016) (Wahyuni, Sulardiono, \& Hendrarto, 2015). Mangroves provide a variety of ecosystem services, including nutrient cycles, soil formation, wood production, fish spawning sites, ecotourism and carbon storage (Murdiyarso et al., 2015). Even tropical mangrove forests are important coastal ecosystems that support various aspects, ranging from small-scale fisheries to human populations (Santos, Gasalla, Dahdouh-Guebas, \& Bitencourt, 2017). The uniqueness of mangrove habitats has contributed to the economic development of a number of countries through the expansion of ecotourism activities. Declining mangrove ecosystems and habitat fragmentation are causing major problems in all tropical countries in the world (Mijan Uddin, Rafiqul Hoque, \& Abdullah, 2014). Mangrove forests can also reduce the impact of tidal floods caused by tides and high rainfall (Giarno, Didiharyono, Fisu, \& Mattingaragau, 2020). Careful considerations need to be taken to ensure that mangrove ecosystems are well preserved and protected through ecotourism activities (Azis, Sipan, Sapri, \& Zafirah, 2018).

Mangrove ecotourism has a natural attraction that is increasingly in demand by the community. From year to year, this mangrove ecotourism shows an increase in the number of visitors so it is necessary to know the carrying capacity and development strategies so that visitors remain comfortable in the tourism location (Murtini, Kuspriyanto, \& Kurniawati, 2018).

Wakatobi Regency is a group of islands which was originally known as Tukang Besi Islands, which is included in the administrative area of Buton Regency, Southeast Sulawesi Province. Since 2003, based on Law No.29 of 2003 Wakatobi Regency has become an autonomous region which is a division of Buton Regency. Wakatobi is short for the name of 4 large islands in the Wakatobi region, namely
Wangi-Wangi Island, Kaledupa Island, Tomia Island and Binongko Island. Wakatobi is an island district that has an area of 1,390,000 ha consisting of 39 small islands, 3 shoals and 5 atolls.

The distribution of mangrove vegetation in Wakatobi Regency should be seen as a potential that can provide economic value to the community and provide added value to local governments in addition to underwater natural exploration. Mangrove forest conservation should also be able to provide economic returns so that the concept of green economy can be implemented to achieve sustainable management goals. So, it is deemed necessary to study the development of the potential of mangrove ecosystems in Wakatobi Regency so that it can be beneficial both as a buffer for the coastal environment and economically beneficial for the surrounding community.

\section{Research Methodology}

This type of research is descriptiveevaluative research, with a qualitative approach. Descriptive research can be interpreted as a problem-solving process that is analyzed by describing the current state of the research object based on apparent facts or existing conditions (Fisu 2016). The implementation of descriptive research methods is not limited to the collection and compilation of data, but includes the analysis and interpretation of the data. Then after the data is processed and analyzed, an evaluative process is carried out with the output of the planning concept. The type of data used consists of primary data in the form of high resolution image data and the biophysical appearance of the mangrove ecosystem. Besides that, secondary data is also used in the form of mangrove vegetation composition. The data that has been collected is then used as material for the analysis of the potential for the development of ecotourism complexes and the analysis of planning with output in the form of site designs.

\section{Results and Discussion \\ Potential of Mangrove Ecosystems}

The availability of mangrove vegetation is on all islands in Wakatobi Regency. The existence of the largest mangrove vegetation 
is on Kaleduppa Island, which is almost in all villages (Laulua Village, Langge Village, Sombano Village, Buranga Village, Balasuna Village, Horuo Village, and Tampara Village). Whereas on Wangi-Wangi Island there are in Liya Bahari Village and Togo Liya Village. Mangrove vegetation on Tomia Island is found in Lamanggau Village, Waiti Village, Timu Village, Patipelong Village, and on Binongko Island located in Popalia Village, Taipabu Village, and Makoro Village.

The Rhizophoraceae genus has the highest density reaching 30 individuals per $\mathrm{m} 2$ in the seedling growth stratum. Mangrove vegetation density tends to decrease in the last 4 years at each location and almost all growth strata. The highest vegetation density was in the Wangi-Wangi Island location in the genus Rhizphoraceae seedling and sapling categories, then followed by the second highest density in the Kaledupa Island seedling category. Whereas mangrove vegetation with tree category has the lowest density in all locations. For more details can be seen in the following graph:

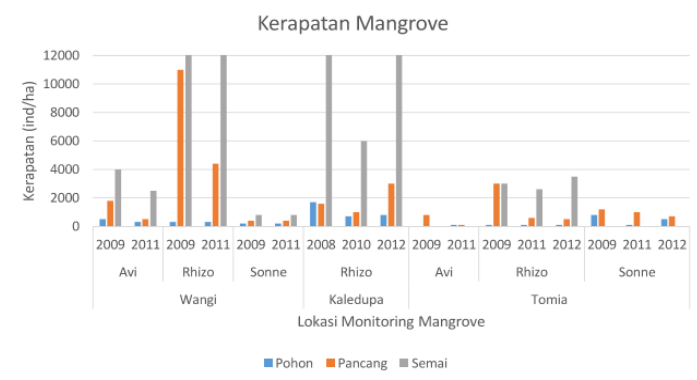

Figure 1. Mangrove Density of Wakatobi Regency

The frequency of a type of mangrove shows the spread of a type in an area. Based on the data found that, the distribution of mangrove species in the community in the last four years is relatively stable with the highest encounter in the genus Rhizophoraceae. The highest frequency for the tree category is found on Kaledupa Island. As for the category of saplings and seedlings, most are found on Kaledupa Island and Wangi-Wangi Island.

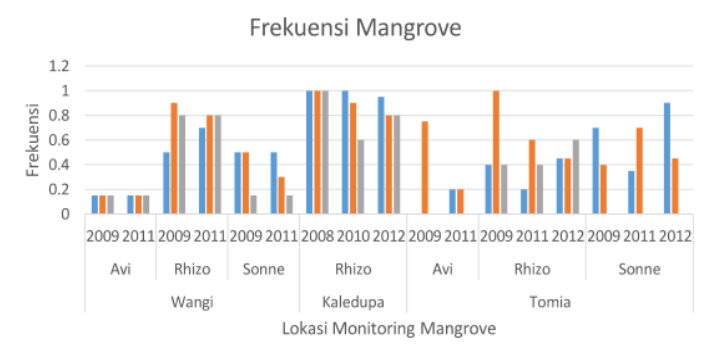

Figure 2. Frekuensi Spesies Mangrove Kabupaten Wakatobi

Dominance is a value that indicates mastery of a type of a community. Based on the data, the genera Sonneratiaceae and Rhizophoraceae are mangroves with the highest mastery of space.

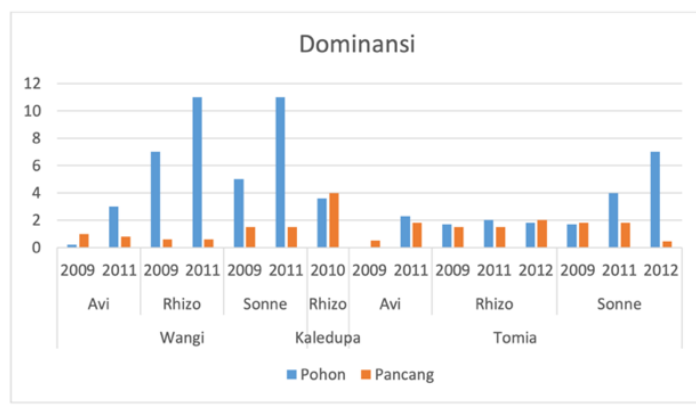

Figure 3. Mangrove Dominance of Wakatobi Regency

The Importance Value Index is the sum of the 3 previous variables for each species. Based on the data, the Rhizophoraceae clan has the highest role in the Wakatobi mangrove community in every monitoring. Of all the variables, the highest Importance Value Index for the genus Rhizophoraceae is on Kaledupa Island with a fairly balanced tree, sapling and seedling category

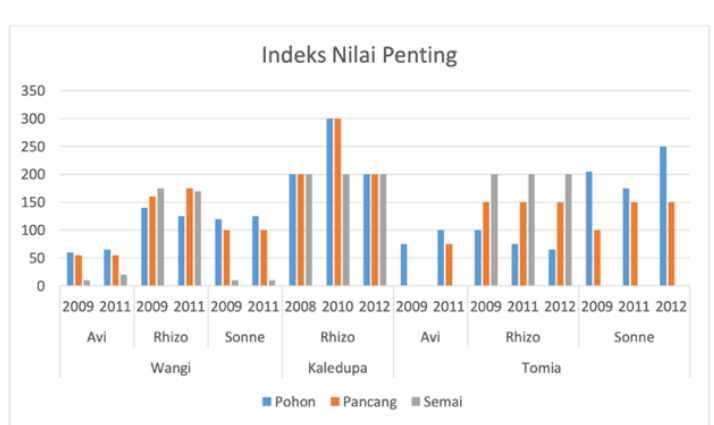

Figure 4. Mangrove Importance Value Index of Wakatobi Regency 
The diverse composition of mangroves in the Wakatobi Islands complex is an excellent potential for the development of mangrove ecotourism. Based on the analysis of the potential species composition, mangrove area and development policy, the development of mangrove ecotourism is prioritized on Kaledupa Island. The total area of mangroves on Kaledupa Island is around 1730 hectares with a composition of 24 mangrove species dominated by the Rhizophoraceae family.

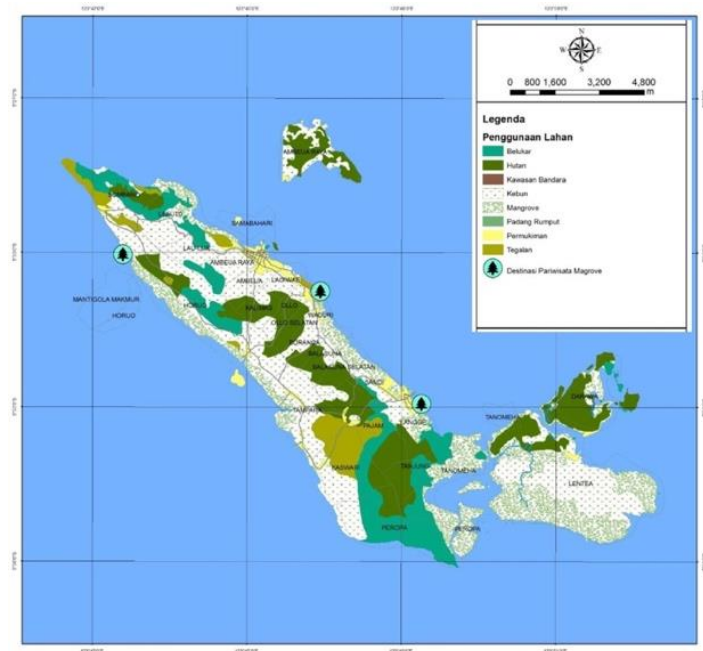

Figure 5. Kaledupa Island Land Use

\section{Identification of Kaledupa Island Tourism Potential}

Kaledupa Island is one of the main islands in the Wakatobi district. The morphology of the land is in the form of valleys with an altitude of 0-20 m above sea level, scattered around coastal areas with a relatively narrow range. The land above stretches undulating hills from Sampano to Peropa. Hoga Island and small islands in Kaledupa District are flat islands with very low relief, less than $5 \mathrm{~m}$ above sea level. Likewise, the small islands in the South Kaledupa District are dominated by the morphology of valley land. Lentea Kaledupa Island is located at an altitude of 0 $35 \mathrm{~m}$ above sea level, there are hills in the middle of the island. Darawa Island is entirely valley land with an altitude of $0-50 \mathrm{~m}$ above sea level.

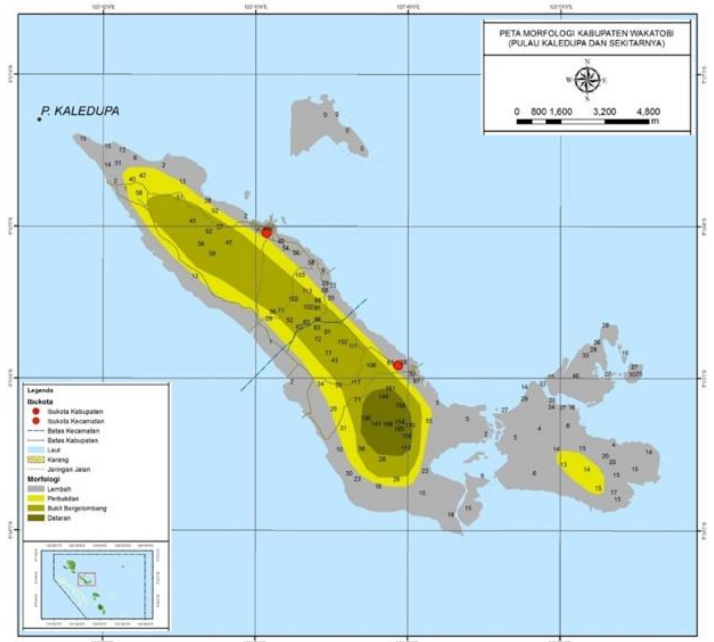

Figure 6. Land Morphology of Kaledupa Island

Kaledupa Island is the second largest island after Wangi-Wangi Island which holds a variety of tourism potential both in the ocean and inland. Existing tourism potential consists of beaches, lakes, caves and plateaus. The beaches that are frequently visited by tourists are Peropa Beach, located in Peropa Village and Sombano Beach, located in Sombano Village.

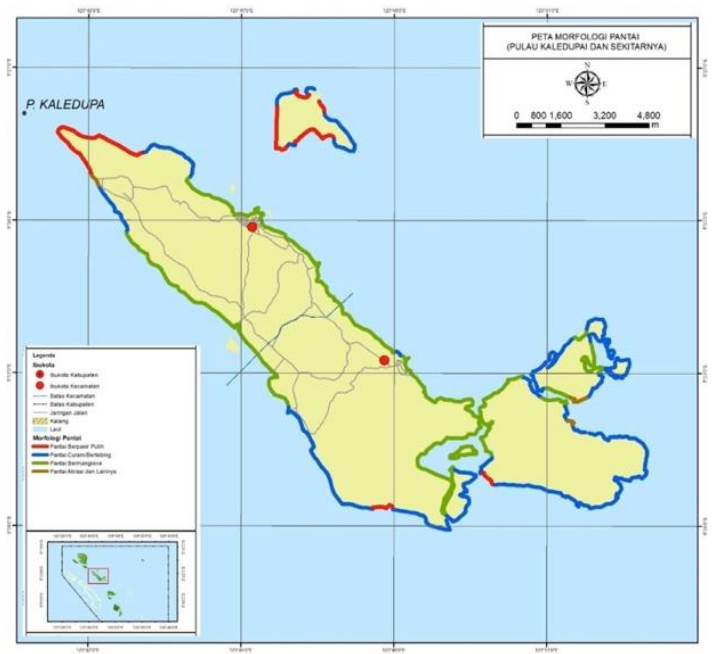

Figure 7. Coastal Morphology of Kaledupa island

There are also attractions of historical and cultural sites in the form of Darawa Cave, Pajam Village, and 4 Fortresses from the colonial era. The island also has a lake ecosystem located in the village of Sombano. This lake is a habitat for several types of marine life such as coral reefs, red shrimp and several types of fish. The location of the lake surrounded by limestone and mangrove forests makes this place more attractive. Tourists can also enjoy Bajo Mantigola and Bajo Sampelas villages. The annual event held 
on this island is the Barata Kaledupa Festival. Kaledupa Island was chosen based on the availability of the most mangrove ecosystems and several other supporting variables which have been described in the analysis process. Kaledupa Island is then considered the most potential to be discussed in more detail about its development, which is planned as a mangrove conservation and ecotourism area. Mangrove Area of Sombano Village and Surrounding Areas is designated as a mangrove tourism area which is equipped with supporting infrastructure.

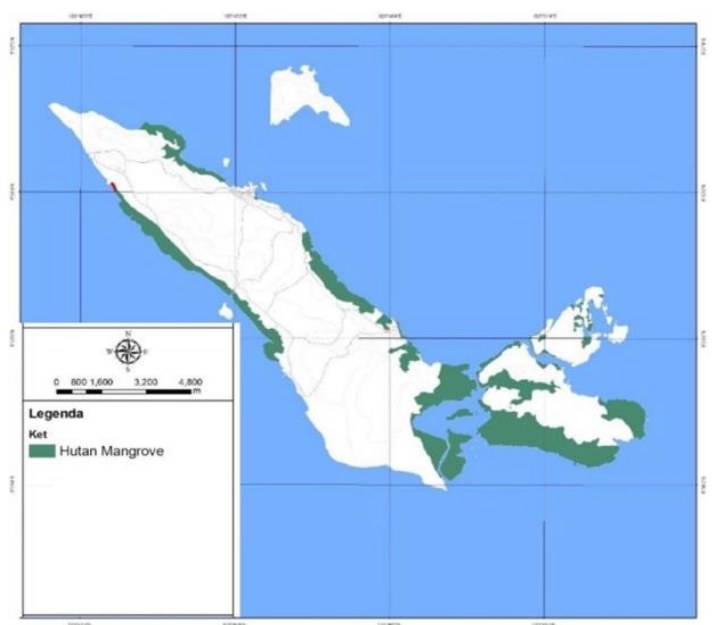

Figure 8. Mangrove Distribution of Kaledupa Island

\section{Mangrove Ecotourism Planning}

In the framework of empowering and developing mangrove forests in Kaledupa Island, mangrove forests need to be packaged as a concept of conservation and nature-based tourism. Nature-based tourism or ecotourism is a tour that focuses on the natural environment, which is selling products and markets based on nature.

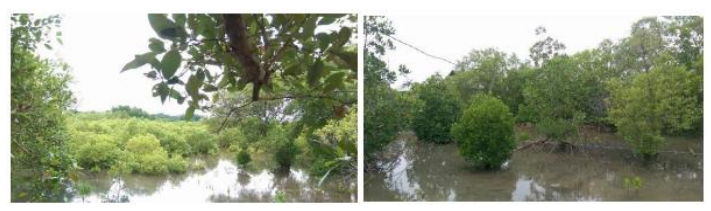

Figure 9. Mangrove vegetation on Kaledupa Island

Conservation of mangrove forest natural resources is fundamental in the development and management of intended natural tourism. The intended nature tourism consists of various activities that can be done by visitors, including enjoying the mangrove forest ecosystem of Kaledupa Island with a variety of flora and fauna in it, bird watching, jogging
\& mangrove tracks, water tourism attractions (boat tours and water sports).

Aside from being a nature tourism facility, the Kaledupa Island mangrove forest can also be an educational tourism facility. The mangrove forest environment is expected to provide lessons for visitors and surrounding communities. Mangrove forests are expected to create a pleasant, meaningful, caring, and appreciative environment. Sustainability of the mangrove forest environment in the long run can run with educational activities. In addition, Wakatobi mangrove forests can also be used as a center for research and development of science and technology. There are many coastal ecosystems including flora and fauna that can be used as learning and research for the community and visitors. Mangrove forest tours can be realized with the nursery/mangrove seedling area, Mangrove Information Center, and bird breeding sites.

The development of mangrove forest tourism in Kaledupa Island is expected to play a role in the conservation of natural resources (the mangrove forest itself) and to assist local communities in fulfilling their welfare. Tourism development can change the quality of life, socio-economic structure, and social organization in local communities. Conservation of mangrove ecosystems through ecotourism can increase the role of mangroves in climate change mitigation efforts as carbon sinks and storage. If you look at the potential of mangrove reserves from several studies stating that the potential of mangrove carbon reserves is very high both in above ground carbon and below ground carbon.

In supporting the development of mangrove ecotourism areas on Kaledupa Island, it is necessary to support tourism facilities that can facilitate all visitor activities. The concept of developing mangroves, especially as a tourism area, is implemented in the form of developing mangrove forest tourism areas with spatial planning, access, touring plans, and facilities as well as supporting infrastructure that is environmentally friendly and does not damage the mangrove ecosystem. Here are some plans for supporting facilities in the Kaledupa Mangrove Forest Ecotourism Area. 
One of the planned facilities to be developed on Kaledupa Island is the Kaledupa Information Center, located in the center of Kaledupa Island, the village of Ambeua. This place is intended as a center for information about all the things that exist on Kaledupa Island. Tourists can get information on tourist areas, homestays, and other facilities at the Kaledupa Information Center.

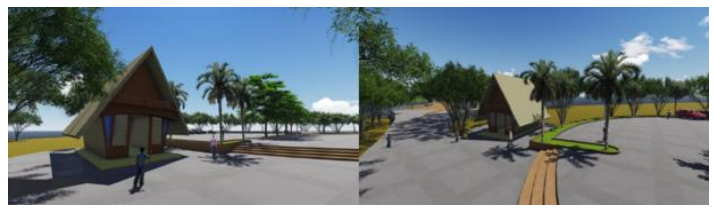

Figure 10. Kaledupa Information Centre Planning

An important facility that must be owned by an ecotourism area is an accommodation facility. The planned accommodation facilities in the mangrove ecotourism area of Kaledupa Island are in the form of a homestay and Gazebo. Basically, there are already a number of hotels and guesthouses available on Kaledupa Island, but the development of a new homestay will be planned in the Mangrove Area of Sombano Village and its surroundings by utilizing local communities as homestays. As one embodiment of the principle of local ownership, people are given the opportunity to exploit the potential by renting out residences as homestays to tourists. In addition, beach gazebos are also planned for tourist areas. Gazebo is managed and given direct responsibility to the local community. This is expected to improve the local economy.

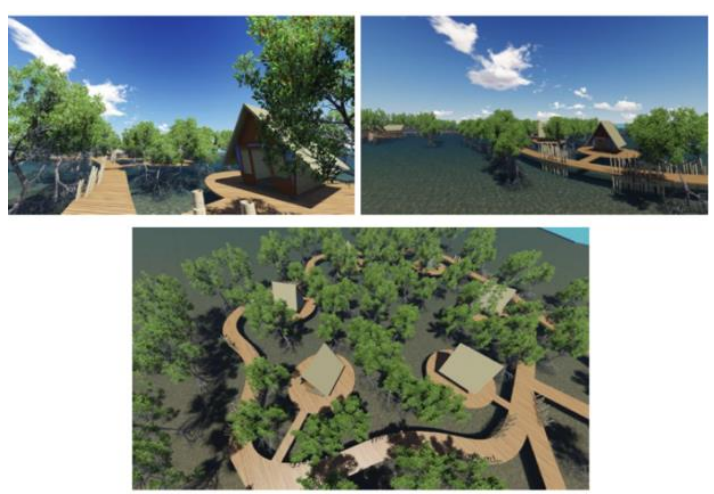

Figure 11. Accomodation Facility Planning

The trade facility that will be planned is in the form of a restaurant that provides typical foods of Wakatobi Regency which are managed directly by the local community. In addition, souvenir shops are also planned to peddle the results of the use of mangroves by local communities such as food crafts, batik mangroves, and so forth.

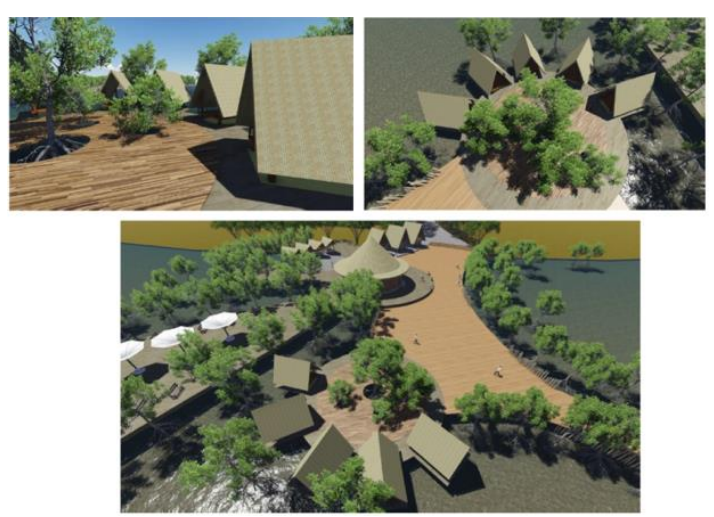

Figure 12. Trade Facility Planning

Service facilities to be planned in the mangrove ecotourism area are in the form of a mangrove information center and public toilets. Public toilets will be placed at several points with a radius of 400 meters. Radius 400 meters is a distance that is still relatively comfortable to walk (Fisu, 2017). Mangrove Information Center can be a learning facility for tourists, Kaledupa mangrove ecotourism area is also equipped with a mangrove nursery area that can be a learning and research facility for tourists.

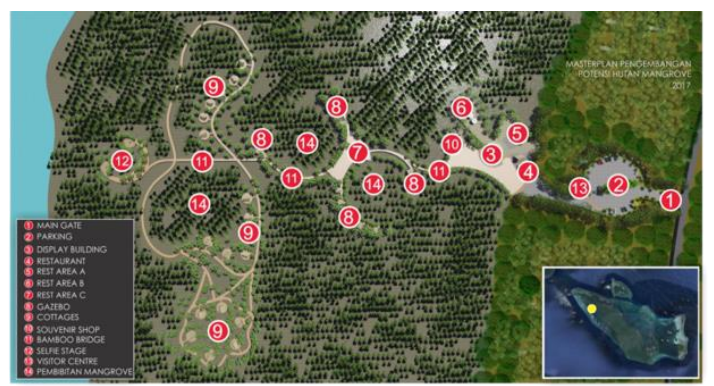

Figure 13. Mangrove Tourism Development Siteplan of Kaledupa Island

\section{Conclusion}

Based on the results of research and analysis of the development of ecotourism on Kaledupa Island, some conclusions can be obtained are: The potential of mangrove ecosystems on Kaledupa Island is very diverse with a fairly large area. Required physical development of supporting facilities and infrastructure on Kaledupa Island to improve the quality of mangrove ecotourism. Facilities that need to be built include accommodation facilities, trade facilities and supporting facilities. 


\section{References}

[1]. Ahmad, A., Wirakartakusumah, M. B. S., \& Rusolono, T. (2016). Model Spasial Deforestasi Di Kphp Poigar, Provinsi Sulawesi Utara (Spatial modeling of deforestation in FMU of Poigar, North Sulawesi). Jurnal Penelitian Kehutanan Wallacea Vol. 5 No.2, Agustus 2016: 159169.

https://doi.org/10.18330/jwallacea.2016.vol5 iss2pp159-169

[2]. Azis, S. S. A., Sipan, I., Sapri, M., \& Zafirah, A. M. (2018). Creating an innocuous mangrove ecosystem: Understanding the influence of ecotourism products from Malaysian and international perspectives. Ocean and Coastal Management, $\quad 165, \quad 416-427$. https://doi.org/10.1016/j.ocecoaman.2018.09 .014

[3]. Basyuni, M., Bimantara, Y., Siagian, M., Wati, R., Slamet, B., Sulistiyono, N., Leidonad, R. (2018). Developing community-based mangrove management through eco-tourism in North Sumatra, Indonesia. In IOP Conference Series: Earth and Environmental Science (pp. 1-7). https://doi.org/10.1088/1755-

1315/126/1/012109

[4]. Fisu, A. A. (2017). Potensi Demand Terhadap Pengembangan Kanal Jongaya \& Panampu Sebagai Moda Transportasi (Waterway) Di Kota Makassar. Jurnal Manajemen Transportasi Dan Logistik. https://doi.org/10.25292/j.mtl.v3i3.68

[5]. Fisu, A. A., Didiharyono, D., \& Bakhtiar. (2020). Economic \& Financial Feasibility Analysis of Tarakan Fishery Industrial Estate Masterplan. IOP Conference Series: Earth and Environmental Science, 469, 1-7. https://doi.org/10.1088/17551315/469/1/012002

[6]. Fisu AA. (2016). Analisis dan Konsep Perencanaan Kawasan Pelabuhan Kota Penajam Sebagai Pintu Gerbang Kabupaten Penajam Paser Utara Kalimantan Timur. Pena Teknik: Jurnal Ilmiah Ilmu-ilmu Teknik. 1(2). 125-136

[7]. Giarno, G., Didiharyono, D., Fisu, A. A., \& Mattingaragau, A. (2020). Influence Rainy and Dry Season to Daily Rainfall Interpolation in Complex Terrain of Sulawesi. In IOP Conference Series: Earth and Environmental Science. https://doi.org/10.1088/1755-

1315/469/1/012003

[8]. Hakim, L., Siswanto, D., \& Makagoshi, N. (2017). Mangrove Conservation in East Java: The Ecotourism Development Perspectives.
Journal of Tropical Life Science, 7(3), 277285. https://doi.org/10.11594/jtls.07.03.14

[9]. Hugé, J., Vande Velde, K., BenitezCapistros, F., Japay, J. H., Satyanarayana, B., Nazrin Ishak, M., Dahdouh-Guebas, F. (2016). Mapping discourses using Q methodology in Matang Mangrove Forest, Malaysia. Journal of Environmental Management, 183(3), 988-997. https://doi.org/10.1016/j.jenvman.2016.09.0 46

[10]. Idajati， H., Pamungkas， A., \& Vely Kukinul, S. (2016). The Level of Participation in Mangrove Ecotourism Development, Wonorejo Surabaya. Procedia - Social and Behavioral Sciences, 227, 515520.

https://doi.org/10.1016/j.sbspro.2016.06.109

[11]. Mijan Uddin, S. M., Rafiqul Hoque, A. T. M., \& Abdullah, S. A. (2014). The changing landscape of mangroves in Bangladesh compared to four other countries in tropical regions. Journal of Forestry Research. https://doi.org/10.1007/s11676-014-0448-z

[12]. Murdiyarso, D., Purbopuspito, J., Kauffman, J. B., Warren, M. W., Sasmito, S. D., Donato, D. C., Kurnianto, S. (2015). The potential of Indonesian mangrove forests for global climate change mitigation. Nature Climate Change, 5, 1089-1092. https://doi.org/10.1038/nclimate2734

[13]. Murtini, S., Kuspriyanto, \& Kurniawati, A. (2018). Mangrove area development strategy wonorejo as ecotourism in surabaya. Journal of Physics: Conference Series, 953, 012174 . https://doi.org/10.1088/17426596/953/1/012174

[14]. Nugraha, B., Banuwa, I. S., \& Widagdo, S. (2015). Perencanaan Lanskap Ekowisata Hutan Mangrove di Pantai Sari Ringgung Desa Sidodadi Kecamatan Padang Cermin Kabupaten Pesawaran. Jurnal Sylva Lestari, $3(2)$, 53-66. https://doi.org/10.23960/js12353-66

[15]. Santos, L. C. M., Gasalla, M. A., DahdouhGuebas, F., \& Bitencourt, M. D. (2017). Socio-ecological assessment for environmental planning in coastal fishery areas: A case study in Brazilian mangroves. Ocean and Coastal Management, 138, 6069.

https://doi.org/10.1016/j.ocecoaman.2017.01 .009

[16]. Wahyuni, S., Sulardiono, B., \& Hendrarto, B. (2015). Strategi Pengembangan Ekowisata Mangrove Wonorejo, Kecamatan Rungkut Surabaya. Diponegoro Journal of Maquares, 4(4), 6670. 